\title{
Utilização da ultrassonografia no diagnóstico de afecções das artérias umbilicais
}

Caroline Harumi Seino, Juliana Aparecida Bombardelli, Bruna Barbosa Stanigher, Gabriela Alves Reis, Carolina de Lara Shecaira, Milton Ricardo Azedo, Fabio Celidonio Pogliani, Fernando José Benesi"

Faculdade de Medicina Veterinária e Zootecnia, Universidade de São Paulo (USP), São Paulo, SP, Brasil

*Autor correspondente

e-mail: febencli@usp.br

\section{Resumo}

Em bezerros neonatos são frequentes as infecções dos componentes umbilicais, quer seja por essas estruturas representarem porta de entrada de patógenos, quer seja por haver com frequência negligência nos cuidados para cura do umbigo. Considerados os prejuízos decorrentes dessas enfermidades e a necessidade de serem diagnosticadas precoce e precisamente para a escolha do tratamento mais efetivo, estudos tâm sido realizados para se confirmar a ultrassonografia como método de diagnóstico mais sensível quando comparado à palpação abdominal. 0 presente relato clínico confirma a importância dessa alternativa diagnóstica em dois bezerros machos da raça Holandesa, com 15 e 25 dias de vida, e que apresentaram onfalopatias. No animal mais jovem verificou-se hipertermia e apatia, e à palpação abdominal, evidenciou-se formação, com consistência macia, menor que cinco centímetros de diâmetro, em região hipogástrica. No bezerro mais velho constatou-se apatia e diarreia (fezes enegrecidas) e por meio da palpação abdominal, presença de massa em região hipogástrica, com consistência firme e formato arredondado, tendo aproximadamente 15 centímetros de diâmetro. A partir de tais achados lançou-se mão do exame ultrassonográfico a fim de identificar quais estruturas ou órgãos estavam efetivamente envolvidos, com o intuito de planejar um adequado esquema terapêutico. No ultrassonograma do bezerro mais jovem, confirmou-se existência de uma estrutura elíptica com três centímetros de diâmetro menor, em porção da artéria umbilical esquerda próxima à vesícula urinária, com conteúdo heterogêneo (com porção anecoica e outra hipoecoica), envolta por cápsula. No animal mais velho, verificou-se aumento de diâmetro da artéria umbilical esquerda em comparação à direita, e estrutura envolta por cápsula com conteúdo heterogêneo (hipoecoico com pontos hiperecoicos), não sendo possível individualizá-la da parede da vesícula urinária. Em ambos os casos, as estruturas identificadas foram caracterizadas como abscesso (presença de cápsula e conteúdo purulento). À necropsia do bezerro mais jovem confirmou-se a presença de abscesso na artéria 
umbilical esquerda em porção próxima à vesícula urinária. Por sua vez, no bezerro com 25 dias, constatou-se, durante o procedimento cirúrgico para a remoção das estruturas acometidas, uma aderência do abscesso à vesícula urinária e alças intestinais, além de espessamento de porção da artéria umbilical esquerda próxima à formação. Na palpação bimanual do abdômen desses animais, evidenciou-se aumento de volume no trajeto de componentes umbilicais caudais, porém sem a identificação de quais estruturas umbilicais estavam acometidas, se artéria umbilical ou úraco. Por meio do exame ultrassonográfico foi possível a caracterização e localização do componente umbilical afetado com mais precisão, confirmadas posteriormente ao exame necroscópico e durante intervenção cirúrgica. Confirma-se nesta descrição que a ultrassonografia, além de ser um método não invasivo e prático de uso na clínica veterinária, é também uma importante e sensível ferramenta para o diagnóstico, prognóstico e tratamento das afecções umbilicais. 